\title{
GRAND JURY INDICTMENT BASED ON INCOMPETENT EVIDENCE
}

The question of the validity of an indictment based entirely on "incompetent" evidence has been raised in United States $v$. Costello, ${ }^{1}$ a recent case from the $2 \mathrm{~d}$ Circuit, and is now before the United States Supreme Court on certiorari. A Supreme Court decision would resolve this question in the federal system and might also have considerable influence in the states. It is the purpose of this comment to discuss and compare the federal and California law on this subject.

\section{The Federal Law}

The Constitution of the United States provides for the grand jury in federal criminal practice, ${ }^{2}$ and when used, ${ }^{3}$ its indictment is a prerequisite for subsequent prosecution of the accused for a criminal offense. ${ }^{4}$ But both the Constitution and the Federal Rules of Criminal Procedure ${ }^{5}$ are silent as to the kind of evidence which the grand jury may receive and upon which it may find an indictment.

Although the grand jury is often instructed that it shall receive and return an indictment only upon legally competent evidence, ${ }^{6}$ the federal

1221 F.2d 668 (2d Cir. 1955), cert. granted, 76 Sup. Ct. 48 (1955), Note, 69 Harv. L. Rev. 383 (1955). On appeal from a conviction for income tax evasion, one of the points raised was that the court below erred in refusing to dismiss the indictment because no competent evidence was received by the grand jury at the inquest.

2 U.S. ConsT. annend. V: "No person shall be held to answer for a capital, or otherwise infamous crime, unless on a presentment or indictment of a Grand Jury, except in cases arising in the land or naval forces, or in the Militia, when in actual service in time of War or public danger ...." For discussion on the general nature and function of the grand jury, see United States v. Smyth, 104 F. Supp. 283 (1952); Orfield, Crmmal Procedure from Arrest to APPEAL cs. IV \& V (1947); McClintock, Indictment by a Grand Jury, 26 MnNw. L. Rev. 153 (1942); Dession \& Cohen, The Inquisitorial Functions of Grand Juries, 41 YAIE I.J. 687 (1932) ; Morse, A Survey of the Grand Jury System, 10 Ore. L. Rev. 101, 217, 295 (1931); Comment, 4 StaN. L. REv. 68 (1951); Note, 39 Catir. L. Rev. 573 (1951).

3 FED. R. CRnar. P. 7(a), (b). These rules provide that an indictment is unandatory for an offense that is punishable by death, but for offenses punishable by one year imprisonment or at hard labor, the alternative of the information may be used if the defendant waives the prosecution by indictnent in open court. Any other offense may be prosecuted by either indictinent or information. See Dession, From Indictment to Inforntation-Implications of the Shift, 42 YaIE L.J. 163 (1932).

4 Ex parte Bain, 121 U.S. 1, 12 (1887); United States v. Krepper, 159 F.2d 958, 970 (3d Cir. 1946), cert. denied, 330 U.S. 824 (1947).

5 Fed. R. CRDA. P. 6, 7.

6 The charge to the grand jury in $\mathbf{1 8 7 2}$ by Chief Justice Field while on circuit in California has often been repeated with approval. "In your investigations you will receive only legal evidence, to the exclusion of mere reports, suspicions, and hearsay evidence . . . " Charge to Grand Jury, 30 Fed. Cas. 992, No. 18,255, at 993 (C.C.D. Cal. 1872).

In 1954 Chief Judge Yankwich of the United States District Court in California, Southern Division, charged the grand jury in part: "Every indictment which you return is prima facie evidence of the existence of probable cause. And probable cause exists only when there is competent evidence, direct or circuunstantial, before you which leads you, as reasonable persons, to believe that the defendant is guilty of the offense charged.

"Hearsay testimony, i.e., testimony as to facts not known by a witness of his own personal knowledge, but told bim by others than the defendant, is not enough. If there is competent testimony showing probable cause the fact that there nuay also be bearsay testimony becomes unimportant. But there inust be some conjpetent testimony before you, otherwise there is no probable cause . . . " Charge to Grand Jury, 16 F.R.D. 93, 94 (S.D. Cal. 1954). 
circuits are in conflict as to the effect upon an indictment if only incompetent evidence is heard by the grand jury. The 8th Circuit has adopted the rule that the grand jury must indict only on evidence that is competent by trial court standards and that an indictment found only upon incompetent evidence is invalid. ${ }^{7}$ In dicta, the $3 \mathrm{rd}, 4 \mathrm{th}, 5$ th, 9th, and 10 th $\mathrm{Cir}-$ cuits have expressed their approval of this rule. ${ }^{8}$ But the $2 \mathrm{~d}$ Circuit has proclaimed that trial court rules do not necessarily apply to the introduction of evidence before the grand jury, ${ }^{\theta}$ and in United States v. Costello ${ }^{10}$ it was held that an indictment is not invalid merely because it was based entirely on evidence which was incompetent by trial court standards. Judge Learned Hand in the Costello case found that even thougl it was hearsay, ${ }^{11}$ the evidence was rationally relevant and of probative value. Therefore, he held that it was immaterial that the only evidence adduced before the grand jury was hearsay and incompetent by trial court rules. Judge Frank $\mathrm{m}$ his concurring opimon expressed misgivings about a conclusion that an indictment might be based on evidence that would not support a verdict in a trial court and expressed hope that the United States Supreme Court would review and consider the question. ${ }^{12}$ It is this question and conflict that the Supreme Court may now resolve.

It is interesting to note that the view that an indictment based entirely on incompetent evidence is invalid can be traced back to three cases. In United States v. Reed, ${ }^{13}$ Circuit Justice Nelson interrupted counsel's argument with the remark that "evidence before a grand jury must be competent legal evidence, such as is legitimate and proper before a petit jury ...."14

7 Brady v. United States, 24 F.2d 405 (8th Cir. 1928) (held that the lower court erred in denying defendant's offer of proof that there was no competent evidence before the grand jury); Nanfito v. United States, 20 F.2d 376 (8th Cir. 1927) (testimony given by the wife of the accused). See Murdick v. United States, 15 F.2d 965, 968 (8th Cir. 1926), cert. dentied sub nom., Clarey v. United States, 274 U.S. 752 (1927) (hearsay); Anderson v. United States, 273 Fed. 20, 29 (8th Cir. 1921), cert. denied, 257 U.S. 647 (1921); United States v. Kilpatrick, 16 Fed. 765,771 (W.D. N.C. 1883) (hearsay).

8 United States v. Holmes, 168 F.2d 888, 890 (3d Cir. 1948); Cooper v. United States, 247 Fed. 45, 48 (4th Cir. 1917) ; Friscia v. United States, 63 F.2d 977, 980 (5th Cir. 1933); Olmstead v. United States, 19 F.2d 842, 845 (9th Cir. 1927); Gates v. United States, 122 F.2d 571, 576 (10th Cir. 1941), cert. denied, 314 U.S. 698 (1942); Cox v. Vaught, 52 F.2d 562, 563 (10th Cir. 1931). The 1st, 6th, 7th, and D.C. Circuits have yet to make a pronouncement on this question.

9 United States v. Scully, 225 F.2d 113, 116 (2d Cir. 1955).

10221 F.2d 668 (2d Cir. 1955), cert. granted, 76 Sup. Ct. 48 (1955).

11 The evidence found to be hearsay was that given by three government agents who were the only witnesses heard by the grand jury. The agents had had no personal acquaintance with the defendant or his affairs. The first agent was an investigator who had obtained information by circularizing banks by mail. The second agent was an accountant who at the trial identified schedules prepared under his supervision, each of which was based entirely on the testimony given at the trial by witnesses who had not appeared before the grand jury. He also identified a computation based on the schedules and explained them in his capacity of an expert accountant. The third agent vouched for the reconstructed tax returns which had been prepared to reflect the income claimed by the government. Brief for Appellant, pp. 41, 42, United States v. Costello, 221 F.2d 668 (2d Cir. 1955), cert. granted, 76 Sup. Ct. 48 (1955).

12 United States v. Costello, 221 F.2d 668, 679 (2d Cir. 1955), cert. granted, 76 Sup. Ct. 48 (1955).

1327 Fed. Cas. 727, No. 16,134 (C.C.N.D.N.Y. 1852)

$14 I d$. at 735 . He then went on to deny the defendant's motion to quash the indictment. 
In United States v. Farrington, ${ }^{15}$ the court found that in addition to "palpably incompetent evidence," the specially appointed attorney had presented the case against the accused before the grand jury in such a zealous manner as to have prejudiced the grand jurors. The judge in United States $v$. Kilpatrick ${ }^{16}$ was faced with the existent confusion as to the powers, duties, and responsibilities of grand juries in the federal system. Therefore, he applied the state rules of North Carolina and held that "a grand jury ought not find a bill upon evidence merely sufficient to render the truth of the charge probable; their judgments should be convinced that the evidence before them, unexplained and uncontradicted, would warrant a conviction by a petit jury . ..."17

Application of the trial court evidence rules in the present administrative and procedural setting of the federal grand jury system is of doubtful effectiveness because of the great difficulty in discovering their violation, and the lack of an effective procedure to review and raise the issue. ${ }^{18}$ First, the absence of an impartial judicial officer with the grand jury would seem a barrier to effective administration of a comprehensive set of evidence rules. The only judicial officer able to be present at all times during the grand jury hearing is the prosecuting attorney..$^{19}$ It scarcely seems practicable to require that he assume the role of inipartial judge also, limiting himself by rules that may be incompatible with relevancy.

Second, there is a presumption that the grand jury acts regularly, and the burden is upon the one contending otherwise to rebut this presumption by a clear showing of fact. Affidavits of information and belief will

155 Fed. 343 (N.D.N.Y.1881).

1616 Fed. 765 (W.D.N.C. 1883).

17 Id. at 772-73. The court also noted at page 773 that the same test was found in Chief Justice Field's charge to the grand jury wherein he stated: 'Formerly, it was held that an indictment might be found if evidence were produced sufficient to render the truth of the charge probable. But a different and a more just and merciful rule now prevails. To justify the finding of an indictment, you must be convinced, so far as the evidence before you goes, that the accused is guilty-in other words, you ought not to find an indictment unless, in your judgment, the evidence before you, unexplained and uncontradicted, would warrant a conviction by a petit jury ...." Charge to Grand Jury, 30 Fed. Cas. 992, No. 18,255, at 993-94 (C.C.D. Cal. 1872).

18 FED. R. CrRor. P. 12 (a), (b) provide that all objections to the indictment must be raised by a motion to dismiss. The motion inust be made before the plea is entered, although it is within the court's discretion to permit it to be made within a reasonable time thereafter. Failure to move for dismissal constitutes a waiver of all objections except jurisdiction. The court may grant relief from the waiver upon a showing of a good cause.

The motion to dismiss has traditionally been addressed to the discretion of the court, and a higher court will not review or reverse except for an abuse of the lower court's discretion. E.g., Durland v. United States, 161 U.S. 306 (1896); United States v. Rosenburgh, 74 U.S. (7 Wall.) 580 (1868); Stewart v. United States, 300 Fed. 769 (8th Cir. 1924) ; Radford v. United States, 129 Fed. 49 (2d Cir. 1904).

19 FED. R. CRRs. P. 6(d) provides in part: "Attorneys for the government, the witness under examination, interpreters when needed and, for the purpose of taking the evidence, a stenographer may be present while the grand jury is in session . ..." 
not suffice. ${ }^{20}$ This presumption prevails whether the motion is made to dismiss the indictment, ${ }^{21}$ to inspect the minutes of the proceedings, ${ }^{22}$ or merely to have the trial court judge inspect the minutes. ${ }^{23}$

Third, a policy of secrecy in regard to the grand jury proceedings exists. This policy is mamifested in the Federal Rules of Criminal Procedure by the lack of any provision for the endorsement of the names of witnesses appearing before the grand jury to be made on the indictment. ${ }^{24}$ The accused lias no riglit to inspect the minutes of the grand jury proceedings, ${ }^{25}$ and while it is within the court's discretion to make the minutes available, ${ }^{26}$ this discretion is rarely exercised. ${ }^{27}$ Since the accused does not have the right to be present at the grand jury proceedings, ${ }^{28}$ or even to appear to testify, ${ }^{29}$ the only practical inethod available to the accused to discover what transpired and wluo testified is to inquire of the witnesses at the trial. ${ }^{30}$ Even this is sometimes proluibited by the trial court. ${ }^{31}$ The reason most often announced for this policy of secrecy is that the defendant has no right to the secrets of the prosecution's case in advance and will not be allowed to go on a "fishing expedition" for them..$^{32}$ Also emphasized are

20 E.g., Carrado v. United States, 210 F.2d 712 (D.C. Cir, 1954); United States v. Weber, 197 F.2d 237 (2d Cir. 1952) ; United States v. Holmes, 168 F.2d 888 (3d Cir. 1948); Cox v. Vaught, 52 F.2d 562 (10th Cir. 1931); United States v. Sniyth, 104 F.Supp. 283 (N.D. Cal. 1952); United States v. Procter \& Gamble Co., 47 F. Supp. 676 (D. Mass. 1942).

21 Kastel v. United States, 23 F.2d 156 (2d Cir. 1927); United States v. Fujimoto, 102 F. Supp. 890 (D. Hawaii 1952).

22 United States v. Costello, 119 F. Supp. 159 (S.D. N.Y. 1954) ; United States v. Papaioanu, 10 F.R.D. 517 (D. Del.1950); United States v. American Medical Assn., 26 F. Supp. 429 (D.D.C. 1939).

23 United States v. Weber, 197 F.2d 237 (2d Cir. 1952); United States v. Aman, 13 F.R.D. 430 (N.D.IIl. 1953); United States v. Siebrecht, 44 F.2d 824 (E.D.N.Y. 1930).

2418 U.S.C. $\$ 3432$ (1952) is the only enactment which allows the accused to have the names of the witnesses in certain cases. It provides in part: "A person charged with treason or other capital offense shall at least three entire days before commencement of trial be furnished with a copy of the indictment and ... [a list] of the witnesses to be produced on the trial for proving the indictment ...."

25 United States v. Herzig, 26 F.2d 487, 488 (S.D.N.Y. 1928).

26 United States v. Socony-Vacuum Oil Co, 310 U.S. 150, 233 (1940); United States v. Byoir, 147 F.2d 336 (5th Cir. 1945); United States v. Oley, 21 F.Supp. 281 (E.D.N.Y. 1937); United States v. Lydecker, 275 Fed. 976 (W.D.N.Y. 1921).

27 E.g., Carrado v. United States, 210 F.2d 712 (D. C. Cir. 1954) ; United States v. Texeira, 162 F.2d 169 (2d Cir. 1947); United States v. Smyth, 104 F.Supp. 279 (N.D. Cal. 1952); United States v. Owen, 11 F.R.D. 371 (W.D.Mo. 1951) ; United States v. Garsson, 291 Fed. 646 (S.D.N.Y. 1923).

28 United States ex rel. McCann v. Thompson, 144 F.2d 604, 605 (2d Cir. 1944), cert. denied, 323 U.S. 790 (1944); People v. Goldenson, 76 Cal. 328, 345, 19 Pac. 161, 169 (1888). ${ }^{29}$ Duke v. United States, 90 F.2d 840 (4th Cir. 1937), cert. denied, 302 U.S. 685 (1937); United States v. Bolles, 209 Fed. 682 (W.D. Mo. 1913).

30 United States v. Costello, 221 F.2d 668 (2d Cir. 1955), cert. granted, 76 Sup. Ct. 48 (1955).

31 Carrado v. United States, 210 F.2d 712 (D.C. Cir. 1954) (trial court sustained objections to defendant's questioning of government witnesses as to whether they testified before the grand jury).

32 United States v. Weber, 197 F.2d 237, 238 (2d Cir. 1952) ; United States v. Garsson, 291 Fed. 646 (S.D.N.Y. 1923). Judge Learned Hand wrote in part: "Under our criminal pro" cedure the accused has every advantage .... Why in addition he should have the whole evidence against him to pick over at his leisure and make his defense fairly or foully, I have never 
the desirability of preserving the independence and isolation of the grand jury's doings from any kind of judicial control, ${ }^{33}$ and the protection secrecy gives to the jurors, the witnesses, and the accused. ${ }^{34}$

Even should the defendant overcome the obstacles of discovery, there remain two established rules that present almost insurmountable hurdles. First, the courts will not inquire into the weight or sufficiency of the evidence adduced before the grand jury. ${ }^{35}$ Second, and a corollary of the first, all circuits agree that the admission of some incompetent evidence before a grand jury will not invalidate the indictment if there was also some competent evidence presented. ${ }^{36}$ Thus, even a modicum of competent evidence may cure any amount of incompetent testimony. ${ }^{37}$

Even should the Supreme Court reverse the Costello case ${ }^{38}$ and hold that an indictment is not valid if found on entirely incompetent evidence, the operation of the two aforementioned rules will make the practical effect of such a holding slight indeed. Presumably, all that a prosecuter need do to cure the defective indictment is to introduce some competent evidence "no matter how feeble and untrustworthy." 39 It was just this possibility that Judge Hand recognized might result from an opposite holding in the Costello case. He could see no justification for forcing such an "amorphous compromise." 40

\section{The California Law}

The California Constitution provides for either a grand jury indictment

been able to see .... Our dangers do not lie in too little tenderness to the accused. Our procedure has been always haunted by the ghost of the innocent man convicted. It is an unreal dream. What we need to fear is the archaic formalism and the watery sentiment that obstructs, delays, and defeats the prosecution of crime ...." Id. at 649 .

33 In re Kittle, 180 Fed. 946 (S.D.N.Y. 1910). The court stated that "one purpose of the secrecy of the grand jury's doings is to insure against . . . judicial control. They are the voice of the community accusing its members, and the only protection from such accusation is in the conscience of that tribunal .... [T] hey remain what the Grand Assize originally was, and what the petit jury has ceased to be, an irresponsible utterance of the community at large, answerable only to the general body of citizens ...." Id. at 947 .

34 Goodman v. United States, 108 F.2d 516 (9th Cir. 1939).

35 E.g., Chadwick v. United States, 141 Fed. 225 (6th Cir. 1905) ; United States v. Frontier Asthma Co., 69 F.Supp. 994 (W.D.N.Y. 1947); United States v. Morse, 292 Fed. 273 (S.D. N.Y. 1922); United States v. Violon, 173 Fed. 501 (S.D.N.Y.1909).

38 E.g., Holt v. United States, 218 U.S. 245 (1910); Gates v. United States, 122 F.2d 571 (10th Cir. 1941) ; cert. denied, 314 U.S. 698 (1942); Kastel v. United States, 23 F.2d 156 (2d Cir. 1927) ; Hillman v. United States, 192 Fed. 264 (9th Cir. 1911).

37 In addition to the policy of secrecy, these rules have their origin in the fear of administrative burdens upon the courts should they be required to review all grand jury proceedings. Such a procedure would also result in to what amounts to a double trial, once by the court in reviewing the basis of the indictment, and then again by the trial court. The courts are also reluctant to adopt a procedure that may result in the substitution of the court's judgment for that of the grand jury. See United States v. Fitzgerald, 29 F.2d 573 (E.D.Pa. 1928).

38 United States v. Costello, 221 F.2d 668 (2d Cir. 1955), cert. granted, 76 Sup. Ct. 48 (1955).

$39 \mathrm{Id}$. at 678.

10 Ibid? 
or an information as a prerequisite for a criminal prosecution. ${ }^{41}$ In contrast to the absence of federal legislation, the California Penal Code is quite explicit that none but legal evidence should be heard by the grand jury, ${ }^{42}$ and that an indictment should be brought only when the grand jurors feel that the evidence before them, if uncontradicted and uncontroverted, would warrant a conviction by a petit jury. ${ }^{43}$ But until 1942 a basic California rule was that the indictment returned by a grand jury was unimpeachable as far as the kind or amount of evidence heard was concerned.44

The rule of the unimpeachability of the grand jury indictment was modified in 1942. by the California Supreme Court in the leading case of Greenberg $v$. Superior Court. ${ }^{45}$ In the Greenberg case the court examined the transcript of testimony before the grand jury and found "no evidence" ${ }^{46}$ presented of the defendant's guilt of the offense charged. Under such circumstances the court held that the grand jury had acted without authority and that the indictment was void. The court reasoned that the common law rule of the unimpeachability of the indictment was no longer the rule in California because the common law policy of secrecy of grand jury proceedings had been abolished by the amendnient to Penal Code section $925^{4 \tau}$ which required a transcript to be nade of the grand jury tes-

41 CAL. CoNst. art. I, $\S 8$, provides in part: "Offenses heretofore required to be prosecuted by indictment shall be prosecuted by information, after examination and commitment by a magistrate, or by indictment, with or without such examination and commitment, as may be prescribed by law ...."

If the alternative device of the information is utilized, the hearing before the magistrate must determine if there is sufficient cause to beheve the defendant guilty. CAL. PEN. CODE $§ 872$. At this prehminary hearing the accused is present and may be represented by counsel, for unlike the purely inquisitorial nature of the grand jury hearing, this is an adversary proceeding. For that reason the usual rules of evidence prevail and a commitment based on hearsay or other incompetent evidence is unauthorized. See People v. Schuber, 71 Cal. App.2d 773, 163 P.2d 498 (1945); In re Martinez, 36 Cal. App.2d 687, 98 P.2d 528 (1940); In re Schwitalla, 36 Cal. App. 511, 172 Pac. 617 (1918).

42 CAL. PEN. CODE $\$ 919$ provides in part: "The grand jury can receive none but legal evidence, and the best evidence in degree, to the exclusion of hearsay or secondary evidence."

$43 \mathrm{CAC}$. PEN. CoDE $\$ 921$ provides: "The grand jury ought to find an indictment when all the evidence before them, taken together, if unexplained or uncontradicted, would, in their judgment, warrant a conviction by a trial jury."

44 People v. Tinder, 19 Cal. 539 (1862); Morehouse v. Superior Court, 124 Cal. App. 38, 12 P.2d 133 (1932).

4519 Cal.2d 319, 121 P.2d 713 (1942). The defendant was indicted for conspiracy to commit grand theft. He petitioned the Califorma Supreme Court for a writ of prohibition to restrain the trial court from proceeding with the trial after his motion to set aside the indictment was denied and his demurrer to the indictment was overruled. The writ of prohibition was issued.

46 The court did not make it clear whether there was no relevant evidence whatever, or whether there was no admissible evidence. It seemed to imply the former. The court said: "[T]he transcript of the testimony upon which the indictment was based contains no evidence even remotely supporting the charges made against petitioner ...."Id. at 321, 121 P.2d at 715 .

47 CAL. PEN. CODE $\$ 925$ provides in part: "The grand jury . . . must appoint a competent stenographic reporter ... to report the testimony .... If an indictment . . . [is] found ... . against a defendant, the said reporter shall ... file with the county clerk . . . [his] notes. The county clerk shall deliver ... [the] transcript . . . to the district attorney . . . and shall deliver a copy of said transcript upon each ... defendant." 
timony and a copy to be delivered to the defendant and the prosecutor. ${ }^{48}$

To date the California courts have not been presented with the question of the validity of an indictment founded entirely on incompetent, but relevant evidence. Although the courts apply the trial court rules of evidence in their reviews of the grand jury evidence, the holdings have turned on the sufficiency of the competent evidence ${ }^{49}$ or the irrelevancy of the incompetent evidence. ${ }^{50}$ Perhaps some indication of the California solution might be found in the latest reiteration of the rule of the Greenberg ${ }^{51}$ case by the California Supreme Court. In Lorenson v. Superior Court, ${ }^{52}$ the court stated the rule as follows:

"When no evidence has been presented [to the grand jury] to connect him [the accused] with the commission of the crime charged ...., unless there is some rational ground for assuming the possibility that he is guilty," the indictment is void and confers no jurisdiction upon a court to try him for the offense. 53

There would appear to be no reason why probative and relevant evidence, even though technically incompetent, would not furnish that "rational ground." In this connection it is interesting to note that in civil cases the California Supreme Court has held that hearsay not objected to is sufficient to support a finding on a material issue. ${ }^{54}$

Concomitants of the no longer existent rule of the unimpeachability of the indictment, were the rules that the sufficiency of the evidence upon

48 Prior to the amendment of Penal Code section 925 , the only information available to the accused was the endorsement of the list of witnesses examined before the grand jury on the foot of the indictment. CAT. PEN. CODE $\$ 943$.

40 E.g., People v. Wells, 33 Cal.2d 330, 202 P.2d 53 (1949); People v. Trujillo, 32 Cal.2d 105, 194 P.2d 681 (1948); People v. Trieber, 28 Cal.2d 657, 171 P.2d 1 (1946).

50 Dong Haw v. Superior Court, 81 Cal. App.2d 153, 183 P.2d 724 (1947). The defendant was indicted on a charge of conspiracy to bribe. After his motion to set aside the indictment was denied, he petitioned for a writ of prohibition on the ground that the indictment was unsupported by any legal evidence. The court held that only hearsay evidence had been adduced before the grand jury and that this particular hearsay was without any probative value. The writ was issued.

61 Greenberg v. Superior Court, 19 Cal.2d 319, 121 P.2d 713 (1492).

52 35 Cal.2d 49, 216 P.2d 859 (1950). The defendant was indicted for conspiracy to commit robbery. He petitioned the California Supreme Court for a writ of prohibition to restrain the trial court froin proceeding on the ground that the evidence before the grand jury was insufficient to support the indictment. The court held that the circumstantial evidence before the grand jury provided a rational ground for assuming the possibility of defendant's guilt. The writ was denied.

$53 \mathrm{Id}$. at $56,216 \mathrm{P} .2 \mathrm{~d}$ at 863 . The full passage from the Greenberg case is as follows: "A grand jury that indicts a person when no evidence has been presented to connect him with the commission of the crime charged, exceeds the authority conferred upon it by the Constitution and laws of the State of California, and encroaches upon the right of a person to be free from prosecution for crime unless there is some rational ground for assuming the possibility that he is guilty. [Citations omitted.] Such an indictment is void and confers no jurisdiction upon a court to try a person for the offense charged ...." Greenberg v. Superior Court, 19 Cal.2d 319, 322, 121 P.2d 713, 715 (1942).

54 Powers v. Board of Public Works, 216 Cal. 546, 15 P.2d 156 (1932); Parsons v. Easton, 184 Cal. 764, 195 Pac. 419 (1921). Accord, Dorfer v. Delucchi, 61 Cal. App.2d 63, 141 P.2d 905 (1943). See ḾcBanne, Caltrornia Evidence Manual 314 (1945). 
which the indictment was found could not be inquired into by the courts, and that the introduction of incompetent evidence before the grand jury does not affect the validity of the indictment if some competent evidence was also heard. ${ }^{58}$ The rule that the court will not inquire into the sufficiency of the evidence, while still repeated, ${ }^{57}$ appears to have been modified. ${ }^{58}$ In 1949 Penal Code section $995^{59}$ was amended to provide that the indictment must be set aside by the court if the defendant has been indicted without probable cause. ${ }^{60}$ Thus the court has been given the duty to review

55 In re Kennedy, 144 Cal. 634, 78 Pac. 34 (1904); People v. Hatch, 13 Cal. App. 521, 109 Pac. 1097 (1910).

${ }^{56}$ E.g., People v. Nathanson, 134 A.C.A. 52, 284 P.2d 975 (1955) ; People v. Freudenberg, 121 Cal. App.2d 564, 263 P.2d 875 (1953); McFarland v. Superior Court, 88 Cal. App.2d 153, 198 P.2d 318 (1948); People v. Dale, 79 Cal. App.2d 370, 179 P.2d 870 (1947); Stern v. Superior Court, 78 Cal. App.2d 9, 177 P.2d 308 (1947); Borello v. Superior Court, 8 Cal. App. 215, 96 Pac. 404 (1908).

57 See People v. Hopkins, 101 Cal. App.2d 704, 226 P.2d 74 (1951), and People v. Beber, 104 Cal. App.2d 359, 231 P.2d 516 (1951). In both cases the court reviewed the evidence before the grand jury and found there was a sufficient basis for the grand jury to find probable cause of the accused's guilt and the lower courts' dismissals of the indictments were reversed. But see People v. Trujillo, 32 Cal.2d 105, 194 P.2d 681 (1948), involving an automatic appeal from a murder conviction wherein the validity of the indictment was challenged on the ground that the evidence presented to the grand jury was hearsay. The court found that the testimony came within one of the exceptions to the hearsay rule, but intimated that whether sufficiency of evidence before a grand jury could be reviewed on appeal was an open question. The court stated: "Assuming, without deciding, that the question of the sufficiency of the evidence before the grand jury may be reviewed upon appeal ..., it follows that the finding of the indictment of the grand jury was based upon sufficient evidence...." Id. at 115, 194 P.2d at 687 .

58 See ALI Code of CronINax Procedure § 138 (1930) which provides in part that "no mdictment shall be quashed or judgment of conviction reversed on the ground that there was not sufficient legal evidence." It is interesting to note that the Court of Appeals of New York, whose Code of Criminal Procedure sections 256 and 258 contain provisions quite similar to California Penal Code sections 919 and 921, has proclaimed in strong dicta that a defendant has a constitutional right to challenge the sufficiency of the legal evidence before the grand jury. People v. Sexton, 187 N.Y. 495, 80 N.E. 396 (1907) ; People v. Glen, 173 N.Y. 395, 66 N.E. 112 (1903). Both the Sexton and the Glen cases were cited by the California Supreme Court in Greenberg v. Superior Court, 19 Cal.2d 319, 322, 121 P.2d 713, 715 (1942). In 1936, the New York Commission on the Administration of Justice unsuccessfully proposed an amendment to the New York Code of Criminal Procedure, based on the American Law Institute Code of Criminal Procedure section 138. Its recommendation of a constitutional amendinent to overcome the Sexton and Glen cases was also unsuccessful. See SECOND SUPPLEMrentat REPORT or the Comar. on the AdMin. of Jostrce in N.Y. State, Legislative Doc. No. 80, pp. 19-20 (1936).

69 CAL. PEN. CoDE $\S 995$ provides in part that "the indictment or infornation must be set aside by the court in which the defendant is arraigned, upon his motion, in either of the following cases: If it be an indictment: ... (2) That the defendant has been indicted without rcasonable or probable cause ...."

${ }^{60}$ Three procedural devices are available to the accused to question the validity of the indictment: (1) Demurrer to the indictment. (CAL. PEN. CODE $\$ 1004$.) This raises objections as to the face of the indictment and failure to demur constitutes a waiver of those objections, except that want of jurisdiction of the court over the subject of the offense and failure to state facts constituting a public offense are not waived by failure to demur. People v. Schoeller, 96 Cal. App.2d 61, 214 P.2d 565 (1950). (2) Motion to set aside the indictment. (CAL. PEN. CODE $\S 995$.) The ground for this motion is that the defendant has been indicted without probable cause. The motion must be made by the accused in the arraigning court before a demurrer or plea, and a failure to do so constitutes a waiver of any future objections. (CAr. PEN. CODE $\$ 996$.) However, the accused may invole the discretion of the court to permit him to with- 
the sufficiency of the evidence at least to the extent of determining whether the grand jurors could have found probable cause on the basis of the evidence before them. ${ }^{61}$ This represents considerably greater judicial control over the grand jury than federal courts exercise at present.

\section{Conclusion}

The purpose of the grand jury's investigation is not to pass on guilt or innocence, and the indictment is never evidence of the guilt of the accused. ${ }^{62}$ Rather, the purpose of the indictment procedure is to determine if the charge is founded upon credible testimony, ${ }^{63}$ and whether there is probable cause to believe that the accused is guilty of the offense charged. ${ }^{64}$ The grand jury thus limits the powers of the prosecuting attorney ${ }^{65}$ and stands between the prosecutor and the accused, thereby protecting the citizen against unfounded accusation and the expense and vexation of a public trial. ${ }^{66}$

The rationale for the adoption of the trial court evidence standards appears to be the belief that they will best implement the grand jury's function of protecting the accused citizen. ${ }^{67}$ However, the rules of the trial court are not necessarily appropriate to the grand jury proceedings. In some cases, by excluding relevant and probative evidence, the rules may

draw his plea in order to make the motion. People v. Ahern, 113 Cal. App.2d 746, 249 P.2d 63 (1952); People v. Kellogg, 6 Cal.2d 448, 57 P.2d 1304 (1936). A denial of this motion is not appealable, and a review can be secured only on an appeal from the judgment itself. People $v$. Duncan, 50 Cal. App.2d 184, 122 P.2d 587 (1942). (3) Petition for a werit of prohibition to restrain the lower court from proceeding with the trial. (CAL. PEN. CoDE \$ 999a.) The ground for this petition is that the indictment was found without probable cause. Thus, for practical purposes it is a review of the motion to set aside the indictment. Greenberg v. Superior Court, 19 Cal.2d 319, 121 P.2d 713 (1942); People v. Egan, 73 Cal. App.2d 894, 167 P.2d 766 (1946).

61 Prior to the amendment of Penal Code section 995, the test of "probable cause" was apphicable almost exclusively to the preliminary hearing before a magistrate. In that context, probable cause was defined in People v. Nagle, 25 Cal.2d 216, 222, 153 P.2d 344, 347 (1944), as a state of facts as would lead a man of ordinary prudence to believe and entertain a strong sense of suspicion of the guilt of the accused. Probable cause may exist although there may be some room for doubt, and the evidence needed to establish probable cause need not be the same amount that would require a conviction. It was this definition of "probable cause" that has been adopted by the California Supreme Court in Lorenson v. Superior Court, 35 Cal.2d 49, 216 P.2d 859 (1950), in applying the amendment of Penal Code section 995. See text at note 52 supra. Obviously this test is less rigorous than the one announced in section 921 wherein the indictment is not to be found unless the jurors feel that the evidence if uncontroverted would warrant a conviction by a trial jury.

02 Patterson v. Umited States, 183 F.2d 687, 690 (5th Cir. 1950) ; Fontana v. Umited States, 262 Fed. 283, 286 (8th Cir. 1919); Umited States v. Foster, 9 F.R.D. 367, 377 (S.D.N.Y. 1949). 63 Hale v. Henkel, 201 U.S. 43, 59 (1906).

64 Cbarge to Grand Jury, 16 F.R.D. 93 (S.D. Cal. 1954); Charge to Grand Jury, 30 Fed. Cas. 992 No. 18,255 (C.C.D.Cal. 1872); People v. Brown, 81 Cal. App. 226, 253 Pac. 735 (1927); see ALI Code of Crminal Procedure \$145 (1930) which provides: "The grand jurors shall find an mdictment charging the defendant with the commission of an offense when from all the evidence taken together they are convinced that there is probable cause to believe the defendant guilty of such offense."

65 Ex parte Wilson, 114 U.S. 417,426 (1885).

66 Ex parte Bain, 121 U.S. 1, 11, 12 (1887) ; United States v. Kilpatrick, 16 Fed. 765 (W.D. N.C. 1883); United States v. Farrington, 5 Fed. 343,345 (N.D.N.Y.1881) ; Matter of Tyler, 64 Cal. 434, 437, 1 Pac. 884, 887 (1884).

67 See Ex parte Wilson, 114 U.S. 417 (1885). 
actually hinder the grand jury's function and purpose of determining the probable cause of the accused's guilt.

The hearsay rule is illustrative of the foregoing proposition. Hearsay is not inherently irrelevant or non-probative, ${ }^{88}$ as is evidenced by the many exceptions to the rule. ${ }^{69}$ The origin of the rule is found in the development of the adversary system of litigation ${ }^{70}$ and the policy that all evidence and testimony against the accused be subjected to the acid test of oath, confrontation, and cross-examination. ${ }^{71}$ But the nature of the grand jury hearing is not adversary, nor is confrontation or cross-examination available as part of the procedure. ${ }^{7^{2}}$ Therefore, the strict application of the hearsay rule would exclude all hearsay, no matter how relevant or probative, and an indictment found only on hearsay would be invalid notwithstanding the probative value of the evidence in establishing the requisite probable eause.

The approach of Judge Hand in the Costello ${ }^{73}$ case is comparable to that of Dean Wigmore, who has contended that the trial court rules are designed for and are appropriate to the petit jury system, where guilt or innocence are determined, and to apply them to the grand jury system, where only probable cause is sought, would hamper the grand jury in its functions. ${ }^{74}$ In other words, in determining the sufficiency of the evidence presented to the grand jury, all relevant evidence ought to be considered, even though some or all of it might encounter difficulty with the technical exclusionary rules were it to be offered in an adversary rather than in an inquisatorial proceeding. ${ }^{75}$

Whatever the final result in the Costello case, the accused in the federal system will still be faced with difficult procedural problems in attempting to question the sufficiency of the evidence before the grand jury. Therefore, some modification of the present federal rules would seem desirable in order that the defendant might discover the nature of the evidence upon which

68 Model CODE of Evidence rule 1(12) (1942): "'Relevant evidence' means evidenco having any tendency in reason to prove any material matter and includes opinion evidence and hearsay evidence." UNLFORM RULES OF EVImENCE rule 1(2): "Relevant evidence' ineans evidence having any tendency in reason to prove any material fact."

69 MODEx CODE OF EVIDENCE rules 502 and 530 (1942); UNTFORAr RUIEs OF Evidence rules 63(1)-(31) ; Falknor, The Hearsay Rule and Its Exceptions, 2 U.C.L.A.L. REv. 43 n.6 (1954): "An informed layman-one with wide experience as an expert witness-puts it this way: [referring to the fact that hearsay has probative worth] 'As a matter of fact, in the ordinary affairs of life hearsay is a well-recognized source of information, not of course to be inplicitly depended upon but often helpful as one of the steps in an investigation.' OSBORN, THE MIND OF THE JUROR 52 (1937). We all know this to be true-that much of our important day-te-day action is based on 'hearsay.' In other words, everyday experience makes it clear enough that from the layman's viewpoint, 'hearsay,' whatever its deficiencies, is nevertheless 'relevant,' that is, probative ...." See also 5 WIGMORE, EVIDENCE $\$ \$ 1420-1684$ (3d ed. 1940); 6 id. \$\$ 16901810; Ladd, The Hearsay We Admit, 5 OrLA. L. Rev. 271 (1952).

70 Morgan, Introductory NYote, Moded Code of Evidence 217-24 (1942).

71 Id. at $220,221$. (1955).

72 United States v. Costello, 221 F.2d 668, 678 (2d Cir. 1955), cert. granted, 76 Sup. Ct. 48

73 Umited States v. Costello, 221 F.2d 668 (2d Cir. 1955), cert. granted, 76 Sup. Ct. 48 (1955).

741 WigMore, Evidence $\$ 4$ (3d ed. 1940).

75 See 1 id. $\$ 10$. 
his indictment was based so as to secure a review of its sufficiency. In California, where the accused already has the greatest possible rights of discovery and the courts are disposed to examine the grand jury testimony for sufficiency, the rule of relevancy would seem im consonance with the existing rules and recent developments.

William R. Berkman*

* Member, Second-Year Class. 